\title{
KSIĘGOZBIORY KOŚCIELNE W POLSKICH BIBLIOTEKACH CYFROWYCH
}

\section{Wstęp}

Jednym z priorytetowych działań na polu kultury stała się w ostatnich latach digitalizacja dziedzictwa kulturowego, w tym zwłaszcza drukowanych zasobów bibliotek, mająca na celu przeniesienie tych zbiorów na nośniki cyfrowe, a przez to ich ochronę i zachowanie dla przyszłych pokoleń. Zarazem nowoczesna technologia i rozwój Internetu umożliwiają powszechny dostęp do zdigitalizowanych obiektów, co jest nie mniej ważnym deklarowanym celem digitalizacji. $Z$ drugiej strony trwa dyskusja na temat roli i charakteru bibliotek przyszłości - w obliczu faktu, że biblioteki coraz częściej obok tradycyjnych zbiorów gromadzą i/lub udostępniają publikacje cyfrowe i multimedialne. W szczególności dotyczy to udostępniania w bibliotekach za pośrednictwem Internetu komercyjnych czasopism naukowych i książek elektronicznych. Zjawiskiem, które łączy oba te nurty, jest powstanie i dynamiczny rozwój tzw. bibliotek cyfrowych czyli wirtualnych. W swoim wystapieniu chciałbym omówić głównie obecność księgozbiorów kościelnych w polskich bibliotekach cyfrowych, lecz obok tego scharakteryzować również zawartość tych bibliotek pod kątem tematyki teologiczno-religijnej"

\section{Charakterystyka bibliotek cyfrowych}

Brak jest jednej definicji biblioteki cyfrowej, ale za zadowalająca z punktu widzenia bibliotekarza uznaje się na przykład sformułowanie D. J. Watersa: „Biblioteki cyfrowe są organizacjami, które dostarczają środków, włączając wyspecjalizowany personel, dobór, klasyfikację, zapewnienie dostępu, dystrybucji, ochrony danych przed ich modyfikacją i ochrony w sensie fizycznym, tworzenie

\footnotetext{
${ }^{1}$ Wykład stanowi przepracowaną i poszerzoną wersję wykładu wygłoszonego w dniu 19 kwietnia 2008 r. na Sympozjum z okazji 25-lecia Biblioteki Parafialnej w Trzciance pt. Teologiczne zbiory w polskich bibliotekach cyfrowych, „FIDES - Biuletyn Bibliotek Kościelnych”, 1-2 (2007) s. 24-34.
} 
kopii zapasowych i przechowywanie ich w bezpiecznym miejscu, aby mogły być użytkowane przez określoną społeczność lub grupy społeczności" ${ }^{2}$. Podkreśla się tu instytucjonalność takiej biblioteki, która najczęściej jest utrzymywana przez jakąś nadrzędną instytucję, zwłaszcza naukową, np. właśnie klasyczną bibliotekę lub konsorcjum bibliotek.

$\mathrm{Na}$ inny aspekt funkcjonowania bibliotek cyfrowych zwraca uwagę hasło, pochodzące z polskiej Wikipedii, ostatnio bardzo kompetentnie poprawione: „Biblioteka cyfrowa (także: internetowa lub wirtualna; czasem z określeniem elektroniczna) - technologia umożliwiająca udostępnianie w Internecie obiektów w formie elektronicznej, takich jak książki, mapy, dokumenty, zdjęcia, pocztówki, grafika, obiekty audio-wideo, obiekty muzealne, archiwalia itp. [...] Nazwa nawiązuje do klasycznych bibliotek, które wypożyczają zbiory we własnym lokalu, podczas gdy dostęp do biblioteki cyfrowej zazwyczaj może mieć każdy, wszędzie i zawsze, tj. bez wcześniejszego zapisywania się, z każdego miejsca na świecie (gdzie jest dostęp do Internetu) i o dowolnej porze (z wyjątkiem krótkich przerw na konserwację)"3. Tu z kolei podkreślony jest charakter biblioteki cyfrowej jako usługi, dostępnej w Internecie. Trzeba jednak zaznaczyć, że sam zbiór dokumentów umieszczonych na stronach internetowych, bez oprogramowania i bez opracowania, nie stanowi jeszcze biblioteki cyfrowej.

Niejako przy okazji, definicja zaczerpnięta z Wikipedii sama w sobie wskazuje na nowe zjawisko, występujące również coraz częściej w bibliotekach cyfrowych. Jest nim społecznościowy charakter tworzonych w Internecie publikacji, nazywany „Internetem 2.0". Internet 2.0 (Web 2.0) to trend w sieci WWW, polegający na rozpropagowaniu idei współodpowiedzialności za zawartość oraz na dzieleniu się wiedzą. Twórcy Web 2.0 chca, by sieć WWW dawała użytkownikom jak największą możliwość interakcji. Wikipedia jest właśnie takim sztandarowym przykładem wspólnego i interakcyjnego tworzenia encyklopedycznej zawartości. Na gruncie bibliotekarstwa mówi się analogicznie o „Bibliotece 2.0”. W bibliotekach cyfrowych w Polsce ta interakcyjność jest jeszcze najczęściej ograniczona tylko do wpływu na dobór publikacji do digitalizacji (i to tylko w niektórych BC) za pośrednictwem forum dyskusyjnego oraz e-maili. Jednak pojawiły się już niedawno (w programie dLibra 4.0) dalsze możliwości, np. dodawanie on-line do publikacji własnych słów kluczowych oraz ich grupowanie według różnych kryteriów. Kształtuje się zatem nowa płaszczyzna współpracy bibliotekarzy i czytelników i okazja do dzielenia się wiedzą.

To, że biblioteka cyfrowa istnieje jako usługa w przestrzeni Internetu, pociaga za sobą dostępność publikacji, i to o każdej porze, bez konieczności udawania się do odległej nieraz biblioteki i - bardzo często - korzystania ze zbiorów tylko w czytelni. Że jest to dostęp bezpłatny, w przeciwieństwie do licznych serwisów komercyjnych oferujących publikacje elektroniczne, nie trzeba nawet wspominać. Biblioteka cyfrowa umożliwia korzystanie z tych pozycji, które niejedno-

${ }^{2}$ Cyt. za R. Szymula, Biblioteki cyfrowe - zagadnienia ogólne i problemy terminologiczne, EBIB, http://www.oss.wroc.pl/biuletyn/ebib08/szymula.html. Zob. również A. Radwański, Biblioteka wirtualna - problemy definicyjne, EBIB, http://www.oss.wroc.pl/biuletyn/ebib08/radwan.html.

${ }^{3} \mathrm{http}: / /$ pl.wikipedia.org/wiki/Biblioteka_cyfrowa [odczyt: 20 IX 2008]. 
krotnie w ogóle nie byłyby dostępne dla niektórych kategorii czytelników, gdyby nie ich cyfrowa wersja zamieszczona w Internecie (np. stare druki). Dodatkowo otrzymany obraz publikacji jest często lepszej jakości niż oryginał, można go powiększać, a samą publikację w wielu przypadkach (jeśli został wykonany OCR automatyczne rozpoznawanie tekstu) przeszukiwać tekstowo. Ponadto publikacje tekstowe istniejąc w Internecie podlegaja jak wszystkie inne strony internetowe pełnemu indeksowaniu przez roboty wyszukiwarek internetowych, takich jak np. Google, i dzięki temu można odnaleźć interesujące publikacje już nie tylko przy pomocy opisów w katalogach komputerowych tworzonych przez bibliotekarzy, lecz również na podstawie ich treści. Są to wszystko pożytki bibliotek cyfrowych dla czytelników. Również i dla tradycyjnych bibliotek ta cyfryzacja jest pożyteczna: pozwala na zabezpieczenie druków przed zniszczeniem i fizycznym unicestwieniem (kwaśny papier); ułatwia udostępnianie zbiorów specjalnych i rozwiązuje problem wypożyczeń międzybibliotecznych; umożliwia zmniejszenie liczby przechowywanych egzemplarzy. A dla bibliotek kościelnych tego rodzaju bezpłatne i powszechne udostępnianie zbiorów przez Internet stanowi niewątpliwie realizację ich misji ewangelizacyjnej i w związku z tym powinno stać się priorytetem.

Biblioteki cyfrowe, zgodnie z przytoczoną wyżej definicją, udostępniają dokumenty różnego rodzaju: przede wszystkim drukowane dokumenty piśmiennicze (cenne stare druki, książki, gazety i czasopisma, druki ulotne etc.), także jednak rękopisy, mapy, grafiki czy druki muzyczne - przetworzone na postać cyfrową w procesie digitalizacji (np. skanowania). W przypadku publikacji współczesnych są to już zwykle publikacje ,urodzone cyfrowo" (born digital) - czyli od początku powstałe (przygotowane do druku) w formie elektronicznej (nowe książki, czasopisma, rozprawy doktorskie). Oprócz tego w bibliotekach cyfrowych coraz częściej można znaleźć dokumenty elektroniczne, nie mające drukowanego odpowiednika, istniejące wyłącznie w wirtualnym świecie (książki elektroniczne, prezentacje, multimedia).

$\mathrm{Z}$ takim rozróżnieniem na publikacje zdigitalizowane i oryginalnie cyfrowe wiąże się jeszcze jedna, bardzo istotna z punktu widzenia czytelnika, kwestia, a mianowicie problem praw autorskich do prezentowanych dzieł. Powoduje on istnienie zasadniczo prawie 70-letniej cezury pomiędzy tymi dwoma grupami publikacji. Bez problemu można bowiem upowszechniać w Internecie tylko te utwory, do których prawa autorskie wygasły (70 lat po śmierci ostatniego współtwórcy), lub takie, które zostają udostępnione na zasadzie umowy z (żyjącym) autorem lub wydawcą. $Z$ tego powodu tylko niektóre polskie biblioteki cyfrowe pozyskują $\mathrm{i}$ udostępniają współczesne publikacje, najbardziej interesujące dla czytelnika. A jeśli już to robią, to dotyczy to głównie publikacji macierzystych instytucji. Natomiast dzieła liczące co najmniej 70 lat nie są w wielu przypadkach już tak interesujące. Praktyka wyboru druków do digitalizacji jest jednakże taka, by w pierwszej kolejności poddawać temu procesowi obiekty mogące zainteresować szersze grono odbiorców bądź szczególnie związane z misją danej placówki (np. zbiory regionalne lub dotyczące lokalnej historii). Tak np. Biblioteka Papieskiego Wydziału Teologicznego we Wrocławiu umieszcza w Dolnośląskiej Bibliotece Cy- 
frowej materiały dotyczące historii diecezji wrocławskiej oraz przedwojennej działalności Wydziału Teologicznego Uniwersytetu Wrocławskiego. Ten podwójnie lokalny charakter ,gromadzenia” publikacji w bibliotekach cyfrowych nie stanowi jednak wady, gdyż w systemie $d$ Libra jest możliwe (i zalecane) wyszukiwanie we wszystkich bibliotekach jednocześnie. Wręcz przeciwnie, wydaje się, że ten regionalizm sprzyja przyciągnięciu uwagi miejscowych czytelników, a z punktu widzenia bibliotekarzy taka specjalizacja ułatwia unikanie dublowania digitalizacji.

Warto na koniec wspomnieć o technicznej stronie tego rozróżnienia na publikacje „stare” i „nowe” (oryginalnie cyfrowe). Główna różnica polega na dokładności przeszukiwania warstwy tekstowej. Materiał po digitalizacji poddawany jest, jeśli to w ogóle możliwe, procesowi automatycznego rozpoznawania tekstu (OCR), lecz skuteczność oprogramowania w tych przypadkach często jest niezbyt wysoka, a powstałych błędów nikt nie jest obecnie w stanie poprawić. Pozostaje więc warstwa tekstowa, którą nazywa się „,brudnym” OCR. Przeciwnie, publikacje przygotowane komputerowo mają z zasady dostępną pełną warstwę tekstową. Umieszczenie takiej publikacji w bibliotece cyfrowej nie pociąga też większych kosztów, zwykle wystarczy wykonanie pliku w formacie PDF i niewielkie przystosowanie do prezentacji. Gdyby więc udało się pokonać problem praw autorskich, takich publikacji mogłoby być dużo więcej. Na razie jednak publikacje pochodzące $\mathrm{z}$ digitalizacji stanowią zdecydowaną większość.

Rzeczą oczywistą jest, że udostępnianie bezpłatne dla odbiorców pociąga za sobą koszty po stronie bibliotek. I choć również tradycyjne udostępnianie kosztuje, to jednak digitalizacja oraz tworzenie nowych bytów, jakimi są biblioteki cyfrowe, napotyka u nas na trudności finansowe, co szczególnie dotyczy bibliotek kościelnych. Warto jednak zauważyć, że przy rozsądnych ograniczeniach co do jakości skanowania i obróbki publikacji, koszty te nie muszą być i nie są zbyt wysokie.

W Polsce biblioteki cyfrowe rozwijają się stopniowo od 2003 roku, wciąż jeszcze przeważnie dzięki pracy niewielu zapaleńców. Tworzone są głównie przez instytucje akademickie i naukowe, w oparciu o kilka różnych systemów oprogramowania. Największe znaczenie zyskały tworzące wspólną sieć biblioteki cyfrowe środowiska $d L i b r a$, rozwijanego przez Poznańskie Centrum Superkomputerowo-Sieciowe (17 realizacji do połowy września 2008 roku; należy do nich również Księgozbiór Wirtualny Federacji Bibliotek Kościelnych FIDES). Kolejną i szczególną biblioteką jest Cyfrowa Biblioteka Narodowa „Polona”, która używa zmodyfikowanego oprogramowania dLibra. Wspomniane biblioteki oraz kilka innych obejmuje stworzona w Poznańskim Centrum Superkomputerowo-Sieciowym wyszukiwarka zasobów polskich bibliotek cyfrowych o nazwie „Federacja Bibliotek Cyfrowych". Umożliwia ona obecnie jednoczesne wyszukiwanie w 21 bibliotekach. Tych 21 bibliotek cyfrowych będzie dalej przedmiotem analizy. Ponadto istnieje nadal w Internecie, stworzona nakładem ogromnych środków finansowych z budżetu Państwa, Polska Biblioteka Internetowa (PBI), ale od dhuższego czasu jest bytem „martwym” i nie było możliwe włączenie jej do wspólnej wyszukiwarki. 


\section{Księgozbiory kościelne}

Do chwili obecnej żadna z polskich kościelnych instytucji naukowych nie posiada własnej biblioteki cyfrowej. Niestety, nie ma jej nawet największa w Polsce biblioteka kościelna - Biblioteka Katolickiego Uniwersytetu Lubelskiego. Udostępnia ona jedynie na swojej stronie internetowej ok. stu zeskanowanych publikacji. Sa to druki zwarte wydane w XIX w. i do roku 1939 oraz jeden stary druk z 1794 r. (łącznie 86 pozycji) oraz pięć tytułów czasopism z lat 1801-1910. Ponadto sposób udostępniania jest bardzo niewygodny i utrudniający dotarcie do tych publikacji. Dostępny jest bowiem wyłącznie niedokładny spis publikacji (dwie alfabetyczne listy), brak metadanych i wyszukiwarki, a zbiory zapisane są w formacie PDF, bez rozpoznania tekstu, zabezpieczone przed drukowaniem oraz ze znakiem wodnym przez cały obraz stron o treści: „WŁASNOŚĆ BIBLIOTEKA UNIWERSYTECKA KATOLICKIEGO UNIWERSYTETU LUBELSKIEGO JANA PAWŁA II", co bardzo przeszkadza w odczytywaniu publikacji. Taka praktyka jest zupełnym ewenementem na gruncie polskiego bibliotekarstwa cyfrowego, gdzie zasadniczo publikacji się nie zabezpiecza. Wydaje się, że znak wodny - jeśli już to konieczne - mógłby być przynajmniej umieszczony bardziej dyskretnie. Przede wszystkim jednak należałoby życzyć Bibliotece KUL uruchomienia biblioteki cyfrowej z prawdziwego zdarzenia. Szkoda bowiem, że publikowane zbiory są prawie nie do znalezienia.

W takiej zatem sytuacji Federacja Bibliotek Kościelnych „FIDES” zatroszczyła się o zorganizowanie wspólnej dla bibliotek kościelnych platformy cyfro$w^{4}{ }^{4}$. Biblioteka wirtualna (cyfrowa) „FIDES” technicznie została uruchomiona 11 sierpnia 2006 roku, w dzień liturgicznego wspomnienia św. Klary - patronki nowoczesnych mediów, i nosi nazwę „Księgozbiór Wirtualny Federacji Bibliotek Kościelnych FIDES". Uroczystego otwarcia tego serwisu podczas obrad XII Walnego Zgromadzenia „FIDES”, w dniu 27 września 2006 roku, dokonał JE Ks. Biskup Piotr Jarecki, sufragan Archidiecezji Warszawskiej. Księgozbiór Wirtualny FIDES został posadowiony na serwerze specjalnie dedykowanym dla tego celu i jest obsługiwany przez polski program $d$ Libra. Było to dziesiąte w kolejności wdrożenie tego systemu w Polsce. Honorowym gościem uroczystej inauguracji był Marcin Werla z Poznania, przedstawiciel twórców programu dLibra.

Wszystkie biblioteki członkowskie Federacji mają możliwość uczestniczenia w tworzeniu tego wirtualnego księgozbioru. Program dLibra posiada specjalną Aplikację Redaktora, która może być uruchomiona w każdej bibliotece należącej do Federacji „FIDES”. Pozwala ona na samodzielne publikowanie własnych zbiorów w postaci elektronicznej, zgodnie z dostarczoną instrukcją i ustanowionym w tym celu regulaminem. Do chwili obecnej Księgozbiór Wirtualny FIDES współtworzy 13 instytucji oraz 7 autorów indywidualnych.

W połowie września 2008 roku, po dwóch latach funkcjonowania, całkowita liczba publikacji Księgozbioru Wirtualnego FIDES wynosi 488. Na tę liczbę skła-

${ }^{4}$ Z przykrością trzeba zauważyć, że Biblioteka KUL nie należy do Federacji Bibliotek Kościelnych „FIDES”, chociaż uczestniczyła w pracach nad powołaniem jej do życia. 
da się 381 artykułów z czasopism, 49 książek, 38 zeszytów czasopism w całości oraz 20 innych publikacji, w tym cenne inkunabuly i mapy, zebrane w kolekcji „Skarby bibliotek kościelnych”. Najczęściej oglądaną publikacją jest Atlas Minor Gerardi Mercatoris : a I. Hondio plurimis aeneis tabulis auctus atque ilustratus z 1610 r. ze zbiorów Biblioteki Wyższego Metropolitalnego Seminarium Duchownego w Warszawie (ponad 28 tys. odsłon). Specyfikę biblioteki cyfrowej „FIDES” stanowi to, że jej przeważającą częścią są publikacje nowe i najnowsze (por. np. książki z serii „Biblioteka Diecezji Świdnickiej” z 2008 roku); tylko 30 publikacji to zbiory historyczne. Wyjątkowe jest również i to, że zamieszczane są w niej oddzielnie artykuły z kompletnych zeszytów czasopism. W ten sposób publikowane są obecnie cztery czasopisma: „Biuletyn FIDES”, „Perspectiva” (Legnica), „Studia Włocławskie” oraz „Warszawskie Studia Teologiczne”. Rozwiązanie takie ułatwia korzystanie ze zbioru czasopism, przede wszystkim umożliwia wyszukiwanie rzeczowe, w szczególności zdalne (według metadanych) - z innych bibliotek systemu dLibra. Gdyby chcieć porównać wielkość tego zbioru z bibliotekami, które takiego zabiegu rozdzielenia czasopism nie stosują, to trzeba by policzyć tylko całe zeszyty. W ten sposób obliczona sztucznie liczba publikacji w Księgozbiorze Wirtualnym FIDES wyniosłaby 124, ale nadal znaczną przewage stanowiłyby w niej publikacje oryginalnie cyfrowe. Godnym odnotowania jest też publikowanie w BC FIDES na bieżąco czasopisma parafialnego Parafii pw. Odkupiciela Świata we Wrocławiu pt. „Nowe Tysiąclecie” w wersji cyfrowej.

Oprócz Księgozbioru Wirtualnego FIDES trzy biblioteki kościelne umieszczają swoje publikacje cyfrowe w regionalnych bibliotekach cyfrowych. Są to: Biblioteka Archidiecezjalnego Wyższego Seminarium Duchownego w Białymstoku, Biblioteka Papieskiej Akademii Teologicznej w Krakowie oraz Biblioteka Papieskiego Wydziału Teologicznego we Wrocławiu.

I tak Biblioteka Archidiecezjalnego Wyższego Seminarium Duchownego w Białymstoku należy do Konsorcjum Bibliotek Naukowych Miasta Białegostoku i przy wsparciu finansowym ze środków unijnych współuczestniczy w Podlaskiej Bibliotece Cyfrowej (http://pbc.biaman.pl). Ze zbiorów Biblioteki AWSD pochodzi pokaźna liczba 166 publikacji. Oprócz dwóch współczesnych cała reszta to zdigitalizowane cenne zbiory historyczne, częściowo o tematyce religijnej, należące do kolekcji Dziedzictwo kulturowe oraz Regionalia. Prócz tego PBC zawiera pięć tomów czasopisma „Rocznik Teologii Katolickiej”, wydawanego w Uniwersytecie w Białymstoku, w wersji cyfrowej.

Drugą biblioteką kościelną, która umieszcza swój księgozbiór w bibliotekach cyfrowych - a chronologicznie pierwszą - jest Biblioteka Papieskiej Akademii Teologicznej w Krakowie. Weszła ona bowiem najpierw do projektu Polskiej Biblioteki Internetowej i wiele jej wartościowych obiektów w ramach tego projektu zostało zdigitalizowanych. Niestety, projekt nie dość że pochłonął ogromne pieniądze, to jeszcze wykonany został w sposób niezgodny z najlepszą praktyką bibliotekarską. Opisy i katalogi PBI pozostawiają wiele do życzenia, brak całkowicie możliwości wyszukiwania przedmiotowego, nie mówiąc o wyszukiwaniu z poziomu Federacji Bibliotek Cyfrowych. W związku z tą sytuacją w Księgozbiorze Wirtualnym FIDES zostały stworzone pseudo-publikacje, odsyłające do 17 
najbardziej interesujących dla teologów pozycji Biblioteki PAT, zawartych w PBI (stąd obecność Biblioteki PAT w BC FIDES), i w ten sposób również umożliwiające znalezienie ich przez wyszukiwarki. Ostatnio Biblioteka Papieskiej Akademii Teologicznej dołączyła do uczestników Małopolskiej Biblioteki Cyfrowej i pierwsze swoje trzy publikacje umieściła w niej 3 sierpnia br. Są to: Mappografia dawnej Polski Edwarda Rastawieckiego wydana w 1846 r., Nazwy miejscowe polskie Prus Zachodnich, Wschodnich i Pomorza : wraz z przezwiskami niemieckie$m i$ Wojciecha Kętrzyńskiego z 1897 r. i Stownik słowiańsko-polski zawierajacy w sobie mniej teraz zrozumiate, w ksieggach cerkiewnych i do nabożeństwa stużqcych znayduiqce się stowa, dla użytku duchowieństwa, wyznawców obrzqdku greckokatolickiego, miłośników starożytnego ięzyka słowiańskiego, którego autorem jest Josip Levićkij (wyd. we Lwowie w 1830 r.). Publikacje są bardzo dobrej jakości, zeskanowane w kolorze i tam gdzie to możliwe posiadają OCR. Należy się cieszyć, że cenne zbiory Biblioteki PAT będą teraz dostępne coraz obficiej w sieci bibliotek cyfrowych $d$ Libra.

Wreszcie trzecia biblioteka kościelna, która uczestniczy w regionalnym projekcie, to Biblioteka Papieskiego Wydziału Teologicznego we Wrocławiu. Jest ona jednym z 14 członków Konsorcjum Dolnośląskiej Biblioteki Cyfrowej, które powstało 20 grudnia 2006 roku (www.dbc.wroc.pl). Do chwili obecnej Konsorcjum nie otrzymało dotacji, o którą się stara, wszystkie zatem dotychczasowe publikacje zostały wykonane własnymi siłami. Dotyczy to również 121 publikacji Biblioteki PWT, podzielonych na kolekcje: Czasopisma PWT (14), Doktoraty (7), Druki wydane po 1800 roku (86, są to druki zdigitalizowane), Książki wydane w PWT (11) oraz Stare druki (3). Liczba ta stanowi 9\% ogólnego zbioru DBC, który w dniu 17 kwietnia 2008 roku osiaggnął liczbę tysiąca publikacji. Jak widać, większość kolekcji Biblioteki PWT stanowią druki poddane digitalizacji. Są to na ogół niezbyt obszerne, kilkudziesięciostronicowe druki. Dotyczą one historii Kościoła na Dolnym Śląsku oraz dokumentują dorobek naukowy liczącego 300 lat Wydziału Teologicznego Uniwersytetu Wrocławskiego, którego kontynuatorem po wojnie jest Papieski Wydział Teologiczny. Statystyka wskazuje jednak na to, że największą poczytnością cieszą się dzieła współczesne - książki wydane w PWT oraz niepublikowane drukiem doktoraty. Absolutnym rekordzistą jest tu rozprawa doktorska ks. Romana Skarżyńskiego „Struktura organizacyjna Kościoła i życie religijne wiernych okręgu drezdeneckiego w latach 1945-1992" (prawie 7 tys. wyświetleń). Oprócz publikacji w DBC Biblioteka PWT prezentuje 7 pozycji w Księgozbiorze Wirtualnym FIDES - z czego pięć to druki zdigitalizowane, w tym inkunabuł Legenda aurea (Strasbourg, 1482) poddany digitalizacji ze środków Ministerstwa Nauki.

Poniższy wykres prezentuje rozkład liczby publikacji na zdigitalizowane kolekcje historyczne i publikacje współczesne. Biblioteka PAT została pominięta ze względu na początkowy stan dodawania publikacji do Małopolskiej Biblioteki Cyfrowej oraz brak ,nowych” publikacji. 

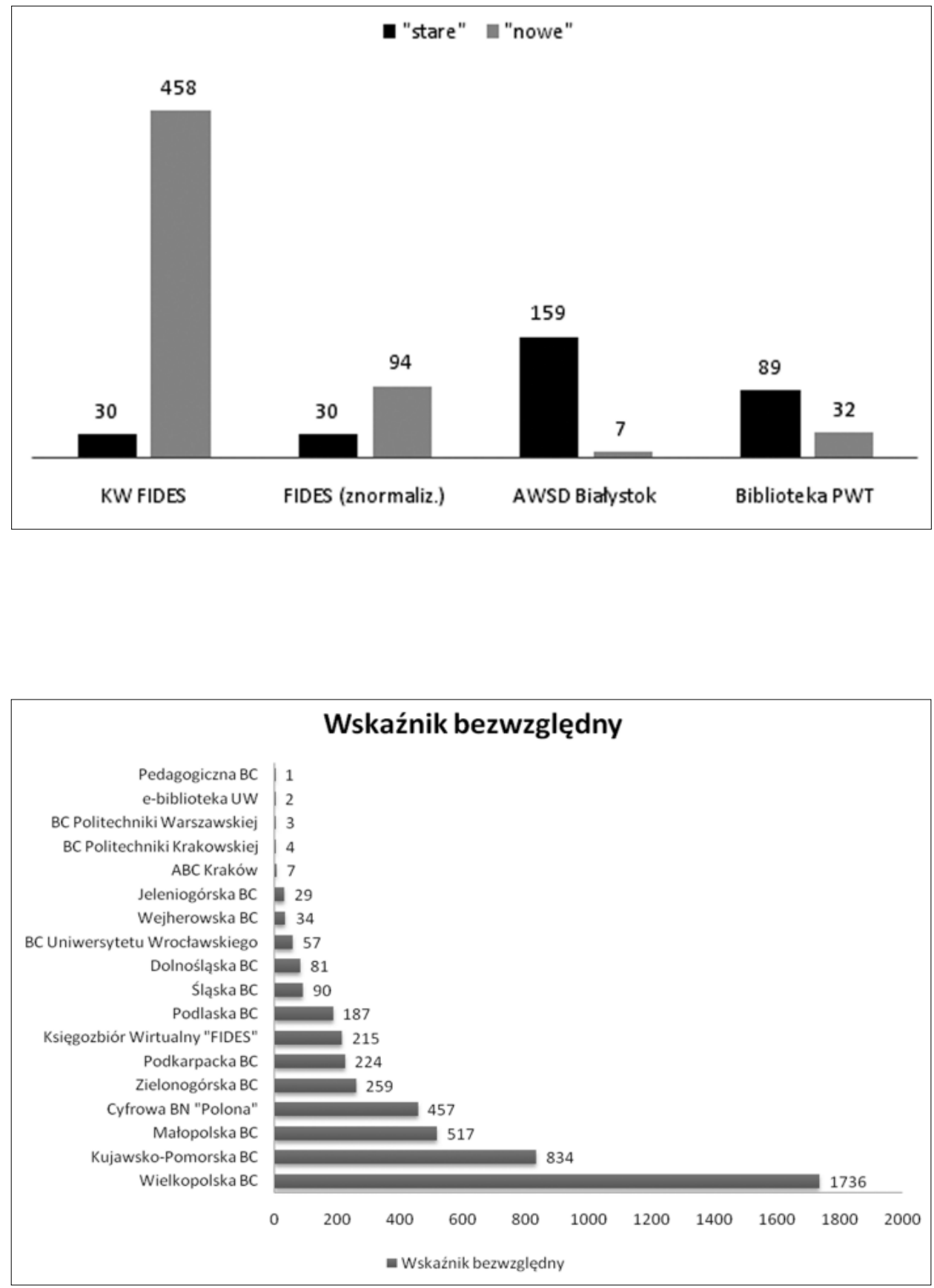


\section{PUBLIKACJE O TEMATYCE RELIGIJNEJ I TEOLOGICZNEJ W BIBLIOTEKACH SYSTEMU DLIBRA}

Według stanu na 21 września 2008 r. liczba dostępnych publikacji w „Federacji Bibliotek Cyfrowych" wynosiła 162 462. Jednocześnie publikacji bibliotek kościelnych było łącznie 783 , co stanowi jedynie niecałe $0,5 \%$. Powinno to być sygnałem alarmowym dla osób odpowiedzialnych za finansowanie polskich bibliotek kościelnych. Wiadomo jednak, że zbiory o tematyce religijnej i teologicznej są gromadzone także w innych niż kościelne bibliotekach. Należy się więc domyślać, że trafiają one również do bibliotek cyfrowych $\mathrm{w}$ ramach digitalizacji dziedzictwa kulturowego. W związku z tym została podjęta wstępna próba zbadania, jakie zasoby o tej tematyce dostępne są w polskich bibliotekach cyfrowych.

Badanie to zostało ograniczone do bibliotek, które wykorzystując oprogramowanie dLibra współtworzą polską platformę rozproszonych bibliotek cyfrowych o nazwie „Federacja Bibliotek Cyfrowych” (http://fbc.pionier.net.pl). FBC jest kolejnym etapem budowy sieci rozproszonych bibliotek cyfrowych w Polsce. Nazwa serwisu FBC odzwierciedla jego charakter - serwis ten jest zbiorem zaawansowanych usług sieciowych opartych na zasobach cyfrowych dostępnych w polskich bibliotekach cyfrowych i repozytoriach. Zasoby te współtworzone są przez wiele instytucji naukowych i publicznych, takich jak wyższe uczelnie, biblioteki, archiwa, muzea czy ośrodki badawcze. Serwis FBC utrzymywany jest przez Poznańskie Centrum Superkomputerowo-Sieciowe afiliowane przy Instytucie Chemii Bioorganicznej PAN. W serwisie tym istnieje m.in. możliwość jednoczesnego wyszukiwania we wszystkich bibliotekach cyfrowych należących do sieci, co zostało wykorzystane do oceny zawartości tych bibliotek.

Podjęto próbę oszacowania wielkości takich zasobów przy pomocy statystyki charakterystycznych słów kluczowych, występujących w całych opisach metadanowych wszystkich publikacji udostępnianych w bibliotekach systemu dLibra. Zostały wybrane jako reprezentatywne następujące słowa: „kościół” (w obu znaczeniach, stąd tak duża liczba wyszukanych publikacji), „religia”, „,katolicyzm”, „Biblia”, „teologia”, „Jezus”. Ze zsumowania wyników (które oczywiście nie są rozłączne) powstał sztuczny wskaźnik do oceny zawartości poszczególnych zbiorów cyfrowych. Dodatkowo obliczono wskaźnik procentowy w odniesieniu do ogólnej liczby publikacji w danej bibliotece, który lepiej pozwala ocenić charakter konkretnego księgozbioru wirtualnego. Wyniki uporządkowane wg wskaźnika procentowego obrazuje poniższa tabela: 


\begin{tabular}{|c|c|c|c|c|c|c|c|c|c|}
\hline \multicolumn{10}{|c|}{$\begin{array}{l}\text { FEDERACJA BIBLIOTEK CYFROWYCH } \\
\text { http://fbc.pionier.net.pl (dane z dnia 21.09.2008) }\end{array}$} \\
\hline Nazwa biblioteki & $\begin{array}{l}\overrightarrow{0} \\
\text { Dे } \\
\text { N }\end{array}$ & 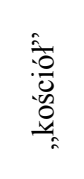 & 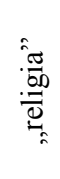 & 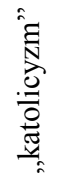 & 吾 & 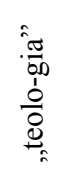 & 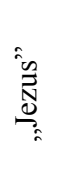 & 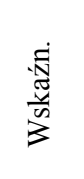 & $\begin{array}{l}\frac{a}{0} \\
\dot{y} \\
\dot{n}\end{array}$ \\
\hline Księgozbiór „FIDES” & 488 & 43 & 6 & 25 & 64 & 53 & 24 & 215 & $44 \%$ \\
\hline Podkarpacka BC & 1434 & 131 & 90 & 3 & & & & 224 & $16 \%$ \\
\hline Dolnośląska BC & 1214 & 31 & 8 & 9 & 7 & 24 & 2 & 81 & $7 \%$ \\
\hline Zielonogórska BC & 4413 & 141 & 5 & 5 & 78 & 11 & 19 & 259 & $6 \%$ \\
\hline Podlaska BC & 4003 & 36 & 76 & 73 & & 1 & 1 & 187 & $5 \%$ \\
\hline Jeleniogórska BC & 640 & 28 & 1 & & & & & 29 & $5 \%$ \\
\hline Kujawsko-Pomorska BC & 20926 & 116 & 715 & 1 & 1 & & 1 & 834 & $4 \%$ \\
\hline Małopolska BC & 13223 & 83 & 14 & 404 & 1 & 15 & & 517 & $4 \%$ \\
\hline Cyfrowa BN „Polona” & 12308 & 216 & 24 & 98 & 72 & 8 & 39 & 457 & $4 \%$ \\
\hline Wielkopolska BC & 65453 & 1516 & 35 & 107 & 26 & 43 & 9 & 1736 & $3 \%$ \\
\hline Wejherowska BC & 2906 & 10 & 4 & 3 & 16 & & 1 & 34 & $1 \%$ \\
\hline Śląska BC & 9209 & 46 & 23 & 5 & 10 & 5 & 1 & 90 & $1 \%$ \\
\hline Pedagogiczna BC & 160 & & 1 & & & & & 1 & $1 \%$ \\
\hline BC Politechniki Krak. & 697 & 3 & & & 1 & & & 4 & $1 \%$ \\
\hline BC Politechniki Warsz. & 703 & 3 & & & & & & 3 & $0 \%$ \\
\hline BC Uniwersytetu Wrock. & 16360 & 14 & 16 & 3 & 6 & 18 & & 57 & $0 \%$ \\
\hline e-biblioteka UW & 963 & 2 & & & & & & 2 & $0 \%$ \\
\hline ABC Kraków & 3679 & 5 & & 1 & & 1 & & 7 & $0 \%$ \\
\hline RAZEM & 158779 & 2023 & 862 & 673 & 256 & 152 & 91 & 4057 & $3 \%$ \\
\hline
\end{tabular}

Jak należało się spodziewać, na pierwszym miejscu pod względem wskaźnika procentowego znajduje się BC FIDES, ale również biblioteki cyfrowe Dolnośląska i Podlaska, w których umieszczają swoje publikacje dwie biblioteki kościelne, znajdują się w czołówce. Potwierdza to słuszność przyjętych założeń badawczych przy tworzeniu wskaźnika zawartości bibliotek cyfrowych. Wart odnotowania jest bardzo wysoki wskaźnik dla Podkarpackiej BC (16\%), jak również wysoka pozycja Zielonogórskiej BC. Stanowi to wskazówkę, które biblioteki cyfrowe przeszukiwać bardziej dokładnie, czyli lokalnie - z ich strony internetowej, z uwzględnieniem również przeszukiwania treści publikacji. Faktycznie, okazuje się np., że w Podkarpackiej BC można znaleźć dużo publikacji dotyczących diecezji przemyskiej obrządku grecko-katolickiego z XIX i XX w., utworzonych przez Wojewódzką i Miejską Bibliotekę Publiczną w Rzeszowie.

Jeszcze ważniejszy okazuje się w takim razie wskaźnik bezwzględny, sumujący wyszukane w opisach interesujące nas terminy. Biblioteki cyfrowe uporządkowane wg tego wskaźnika pokazuje poniższy wykres: 
I tak, najwięcej publikacji o tematyce teologiczno-religijnej możemy się spodziewać kolejno w bibliotekach cyfrowych: Wielkopolskiej (Poznań), KujawskoPomorskiej (Toruń), Małopolskiej (Kraków) czy Cyfrowej Bibliotece Narodowej „Polona”. Przy tych ilościach zdigitalizowanych druków trudno jest omawiać zawartość poszczególnych bibliotek. Warto jednak zauważyć, że oprócz pojedynczych druków możemy w nich znaleźć również całe zbiory dawnych czasopism, przykładowo „Kwartalnik Teologiczny Wileński” (KPBC) czy wszystkie przedwojenne roczniki „Gościa Niedzielnego” (ŚBC). Wydaje się, że w tej sytuacji bibliotekarze powinni częściej sprawdzać poszukiwane tytuły w wyszukiwarce Federacji Bibliotek Cyfrowych. Wskazane byłoby też umieszczanie w katalogach komputerowych aktywnych odnośników do tych publikacji cyfrowych, będących kopią przechowywanych w bibliotece druków.

Opierając się na powyższych, bardzo szacunkowych obliczeniach, można stwierdzić, że publikacje związane z misją Kościoła stanowią tylko kilka procent (ok. 3\%) ogólnej liczby publikacji zebranych w Federacji Bibliotek Cyfrowych. To nadal jest bardzo mało. Ale przecież w bibliotekach kościelnych znajduje się nie tylko literatura o charakterze teologiczno-religijnym, jak to zresztą widać po zestawie zdigitalizowanych już przez nie publikacji. Dużo jest prac z zakresu historii Polski, literatury czy filozofii. Takie dzieła również, a może przede wszystkim, trafiają do bibliotek cyfrowych ze świeckich bibliotek. Uwzględniając ten fakt, jak również i to, że w sieci polskich bibliotek cyfrowych (FBC) istnieje mechanizm zapobiegający dublowaniu digitalizacji - możemy tu mówić o księgozbiorach kościelnych w szerszym sensie. Byłyby to kopie cyfrowe tych druków, które są przechowywane w bibliotekach kościelnych, stworzone i umieszczone w bibliotekach cyfrowych przez jakąkolwiek instytucję. I z pewnością ten cyfrowy „księgozbiór kościelny” jest większy od minimalnego wkładu, wniesionego przez biblioteki kościelne - dzięki zrozumieniu i współpracy wielu świeckich bibliotekarzy, którzy dobrze rozumieją że takie dzieła stanowią nie tylko własność Kościoła, lecz należą do naszego wspólnego dziedzictwa narodowego.

\section{Wnioski}

1. Mimo niezbyt długiego jeszcze czasu istnienia oraz trudności finansowych obecny zasób polskich bibliotek cyfrowych prezentuje się bardzo interesująco, także w aspekcie problematyki religijnej i teologicznej. Można w nim znaleźć wiele ciekawych publikacji, głównie z XIX w. i początków XX w., jak również starych druków. Coraz częściej pojawiają się również i nowe publikacje o tematyce teologicznej: książki, czasopisma (w całości lub rozdzielone na artykuły), prace doktorskie.

2. Publikacje własne bibliotek kościelnych stanowią jedynie niecałe $0,5 \%$ zasobów polskich bibliotek cyfrowych. Powinno to być sygnałem alarmowym dla osób odpowiedzialnych za finansowanie polskich bibliotek kościelnych.

3. Umieszczanie zbiorów w bibliotekach cyfrowych jest dla bibliotek kościelnych oprócz innych pożytków elementem ich misji ewangelizacyjnej. 
4. Lokalizowanie przez instytucje kościelne swoich publikacji pełnotekstowych, czy to cyfrowych, czy to zdigitalizowanych, na własnych stronach internetowych mija się z celem, ponieważ pozostają one słabo widoczne w Internecie. Sens ma jedynie umieszczanie ich w systemie bibliotek cyfrowych, gdzie są one właściwie indeksowane i przeszukiwane.

5. Na tle pozostałych polskich bibliotek cyfrowych wyróżnia się Księgozbiór Wirtualny Federacji FIDES, w którym większość stanowią współczesne publikacje oryginalnie cyfrowe. Wydaje się, że nie jest on jeszcze szeroko znany i odwiedzany (wskazują na to statystyki).

6. Autorzy i wydawcy publikacji o charakterze religijnym mają nowe możliwości dotarcia z nimi do szerokiego kręgu odbiorców poprzez umieszczenie ich w bibliotekach cyfrowych. Federacja Bibliotek Kościelnych „FIDES” zaprasza wszystkich do publikowania w swoim Księgozbiorze Wirtualnym. 